Piotr Karpiński

Akademia Katolicka, Warszawa

ORCID: 0000-0002-1692-3876

e-mail: piotrkar@o2.pl

\title{
Zwrot erotyczny w fenomenologii francuskiej?
}

Rozważania zawarte $\mathrm{w}$ niniejszym artykule wpisują się $\mathrm{w}$ badania specyfiki fenomenologii francuskiej. Nie są one jednak ani wyłącznie historycznofilozoficzne ani czysto przedmiotowe. Innymi słowy, nie zgadzamy się na dość banalne stwierdzenie, że o fenomenologii można albo pisać, albo ją uprawiać1. Przyjmujemy raczej, że w fenomenologii wszystko, co metafilozoficzne, jest także filozoficzne, a więc również jej dzieje i przemiany stanowią problem filozoficzny i odsłaniają nowe zastosowania metody. Jak zauważa Natalie Depraz, fenomenologia nie ma swojego przedmiotu, lecz owocnie czerpie $\mathrm{z}$ innych dyscyplin, a nawet dzięki nim potrafi się odnawiać i zachowywać żywotność ${ }^{2}$ Z $Z$ tego wyni$\mathrm{ka}$, że dzieje fenomenologii nie mogą przypominać linii prostej, lecz wielość promieni wychodzących z jednego centrum. To stałe wybieganie ku nowym obszarom, należałoby powiedzieć: ku nowym fenomenom, i nieustanne poszerzanie swojego horyzontu. Zbiór tez metafilozoficznych, przyjmowanych przez grupę filozofów z początku XX wieku, od Edmunda Husserla poczynając, i odnoszonych do rozmaitych obszarów, wyznaczył kierunki rozwojowe ruchu fenomenologicznego. Z kolei eksplorowanie nowych obszarów owe tezy weryfikowało, modyfikowało i uzupełniało.

1 Por. Witold Płotka, "Słowo wstępne”, w: Wprowadzenie do fenomenologii. Interpretacje, zastosowania, problemy, red. Witold Płotka (Warszawa: Wydawnictwo IFiS PAN, 2014), 8.

${ }^{2}$ Natalie Depraz, Zrozumieć fenomenologię. Konkretna praktyka, przeł. Agata Czarnacka (Warszawa: Oficyna Naukowa, 2010), 3. 
Dzieje ruchu fenomenologicznego są dość dobrze opracowane i nie będziemy im poświęcać uwagi. Chcemy skupić się na polifonicznym obrazie fenomenologii we Francji i odnieść do niego jedno pytanie: czy występuje w nim coś, co można określić jako „zwrot erotyczny”. Pojęcie „Zwrotu” jest jednym, choć nie jedynym, sposobem na opisanie przemian myśli w ramach ruchu fenomenologicznego we Francji. Paul Ricœur posłużył się metaforą herezji ${ }^{3}$, a Jacek Migasiński badał tendencje w filozofii francuskiej połowy XX wieku ${ }^{4}$. Niemniej pojęcie „zwrot”, ze względu na swą operatywność i perswazyjność, robi zawrotną karierę. Najbardziej znany to ogłoszony w 1991 roku przez Dominique'a Janicauda „zwrot teologiczny" ${ }^{5} \mathrm{w}$ fenomenologii francuskiej. Mówi się jednak także o „zwrocie estetycznym" ${ }^{\prime \prime}$, ,zwrocie antropologiczny$\mathrm{m}^{\prime 7}$, „Zwrocie hermeneutycznym "8, ,Zwrocie praktycznym" ${ }^{9}$, „Zwrocie kognitywistycznym"10, „Zwrocie ontologicznym”11, a nawet o „Zwrocie gnostyckim"12 w fenomenologii francuskiej. Chcemy więc zapytać o możliwość odnotowania analogicznego "zwrotu erotycznego", tym bardziej że u francuskich fenomenologów badania seksualności i erotyczności zajmują poczesne miejsce.

$\mathrm{W}$ artykule najpierw podejmiemy problem fenomenologii francuskiej, nakreślając jej zasadnicze cechy. Następnie przyjrzymy się problemowi "zwrotu”, przyjmując za paradygmatyczny ten, który dokonał się w myśli Martina Heideggera - die Kehre. Jest to o tyle zasadne, że fenomenologia francuska wywodzi się zdecydowanie bardziej od

3 Paul Ricœur, A l'école de la phénoménologie (Paris: Vrin, 2004), 9.

4 Jacek Migasiński, W strone metafizyki. Nowe tendencje metafizyczne w filozofii francuskiej XX wieku (Wrocław: Fundacja na Rzecz Nauki Polskiej, 1997).

${ }^{5}$ Dominique Janicaud, Le tournant théologique de la phénoménologie française (Combas: Éditions de l'éclat, 1991).

" Maryvonne Saison, "Le tournant esthétique de la phénoménologie”, Revue d' esthétique 36 (1999): 125-140. Por. Iwona Lorenc, „Ścieżki ku rzeczom samym współczesnej fenomenologii francuskiej", w: Fenomenologia francuska. Rozpoznanialinterpretacje/rozwinięcia, red. Jacek Migasiński, Iwona Lorenc (Warszawa: Wydawnictwo IFiS PAN, 2006), 53.

7 Można zaliczyć tu fenomenologię J.-P. Sartre'a i M. Merleau-Ponty'ego.

8 Jean Grondin, Le tournant hermenutique de la phénoménologie française (Paris: PUF, 2003).

9 Natalie Depraz, "Le tournant pratique de la phénoménologie française", Revue philosopique de la France et de l'Étranger 2 (2004), 149-165.

${ }_{10}$ Bruno Leclercq, "Compte-rendu de Tom Dedeurwaerdere, Action et contexte: Du tournant cognitiviste à la phénoménologie transcendantale", Recherches Husserliennes 20 (2003), 115-118.

11 Paul Gilbert, „Le tournant ontologique de la phénoménologie française?”, Nouvelle Revue Théologique 124-4 (2002), 597-617.

12 Paul Clavier, „Un tournant gnostique de la phénoménologie française?: À propos des Paroles du Christ de Michel Henry", Revue Thomiste 2 (2005), 307-315. 
Heideggera aniżeli od Husserla ${ }^{13}$. Następnie zaprezentujemy tezy w zakresie cielesności, seksualności i erotyczności takich autorów, jak: Maurice Merleau-Ponty, Emmanuel Lévinas, Michel Henry i Jean-Luc Marion. Punktem kulminacyjnym naszych rozważań będzie odpowiedź na pytanie, czy można mówić o zwrocie erotycznym w fenomenologii francuskiej, a jeśli tak, to w jakim sensie.

\section{Problem fenomenologii francuskiej}

Wprawdzie Jean-Luc Marion przestrzegał, że fenomenologia z samej definicji nie powinna zajmować się soba, lecz fenomenami ${ }^{14}$, jednak trzeba na początku przyjrzeć się problemowi „fenomenologii francuskiej”, gdyż jest to kontekst, w którym nasze rozważania się rozwijają. Zarówno Marion, jak i Bernhard Waldenfels zwracają uwagę, że samo sformułowanie "fenomenologia francuska" jest ryzykowne i należałoby raczej mówić o „fenomenologii we Francji” ${ }^{15}$. Zdaniem Mariona nie ma czegoś takiego, jak fenomenologia francuska, podobnie jak nie istnieje fenomenologia niemiecka, a jeśli zdecydujemy się używać tego terminu, to tylko w znaczeniu teoretycznym, a nie narodowym. Sam zaś opowiada się za ostrożnym wyrażeniem: "francuski moment w fenomenologii" i chodzi mu o wyodrębnienie pewnych struktur teoretycznych, które łączą wszystkie pokolenia fenomenologów francuskich, od Lévinasa, poprzez Ricœura, Henry'ego, Jacques'a Derridę, aż po fenomenologów tworzących dzisiaj. Tym wspólnym punktem jest konsekwentne stosowanie trzech operacji składających się na metodę fenomenologiczną: redukcji, analizy intencjonalnej i konstytucji. Marion formułuje swoją ocenę następująco: fenomenologia w ramach swojego "momentu francuskiego" uczyniła niebywały postęp, gdyż zaczęła stosować wspomniane trzy operacje w obszarach, które przez Husserla i Heideggera zostały zignorowane: etyka i skoncentrowanie intencjonalności na Innym (Lévinas i Jean-Paul Sartre), fenomenalność tekstu i literatury (Ricœur, Derrida), cielesność (Merleau-Ponty, Henry). Do tego Marion dorzuca pewną wskazówkę interpretacyjną: francuscy fenomenolodzy torowali drogę do nowych pól, wychodząc od milczących wskazówek Husserla i Heideggera, przekształcali te zapomniane lub marginalne obszary w peł-

${ }^{13}$ Por. Jacek Migasiński, „Fenomenologia francuska jako problem. Topografia «herezji»", w: Fenomenologia francuska, 13.

14 Jean-Luc Marion, „Un moment français de la phénoménologie”, Rue Descartes. Collège international de philosophie, Mars 2002, 9.

${ }_{15}$ Marion, „Un moment français de la phénoménologie”, 10. Bernhard Waldenfels, Phänomenologie in Frankreich (Frankfurt am Main: Suhrkamp, 1983), 10. 
noprawne tematy fenomenologiczne, co poskutkowało rozwojem samej fenomenologii ${ }^{16}$.

Czy w związku z tym możemy mówić o pewnym generalnym, jeszcze bezprzymiotnikowym zwrocie $\mathrm{w}$ fenomenologii francuskiej? Zdaniem Mariona - tak. Zasadniczo daje się on sprowadzić do wypracowania nowego typu redukcji. Fenomenologia francuska nie ujmuje fenomenów ani w perspektywie przedmiotowej, jak czynił to Husserl, ani bytowej, jak ma to miejsce u Heideggera. Raczej korzysta ona $\mathrm{z}$ takich kategorii, jak: cielesność, znak, nadmiar, niewidzialność, inność, a zwłaszcza donacja. Jest to jednocześnie radykalizacja samej fenomenologii, gdyż bycie danym jest idealnym progiem redukcji fenomenologicznej, którego nie da się przekroczyć.

Nieco mniej radykalny od Mariona jest Jean Greisch, który pokazuje większy wpływ niemieckich fenomenologów niż tylko dawanie „,milczących wskazówek". Jego zdaniem Husserl wprowadził do refleksji francuskiej „nowy typ patrzenia”, wszczepił filozofom francuskim, podobnie jak wcześniej Heideggerowi, oczy ${ }^{17}$. W metaforze tej chodzi przede wszystkim o tzw. zasadę zasad, która uprzywilejowuje naoczność i dzięki temu umożliwia widzenie nie tylko konkretnych przedmiotów, ale także samego widzenia. To „odwrócenie wzroku” nosi nazwę „redukcji transcendentalnej". Greisch, w przeciwieństwie do Mariona, o wiele bardziej docenia badania nad historią fenomenologii, gdyż pozwalają one dostrzec kierunek zmian, jaki dokonał się w fenomenologii francuskiej. Proces ten miał jego zdaniem następujący przebieg: filozofowie francuscy, tacy jak: Sartre, Merleau-Ponty, Lévinas, Ricœur, Marion i inni, sięgali wpierw do tzw. tekstów fundacyjnych, głównie Husserla i Heideggera, a następnie twórczo podejmując i uzupełniając ich refleksję, doprowadzali do "nowej fundacji”, do re-fundacji fenomenologicznej ${ }^{18}$. To dlatego Ricœur mógł napisać, że fenomenologia w sensie szerokim jest sumą dzieł Husserla i herezji wobec nich ${ }^{19}$. W ujęciu tym fenomenologia francuska definiowałaby się nie tyle przez uzupełniające podejmowanie tematów rzekomo nieobecnych u Husserla, ile poprzez bezpośrednie odnoszenie się do jego dzieła. Takie określenia, jak "ortodoksja” Husserlowska i "herezja” francuska muszą pozostać metaforyczne, ale jako takie dają do myślenia. Jeśli przywołamy ich pierwotny kontekst religijny, to zobaczymy, że heretyk to nie tyle odstępca od prawdy kanonicznej, co przede wszystkim reformator, a sama ortodoksja może się

16 Marion, „Un moment français de la phénoménologie”, 12.

17 Jean Greisch, „Les yeux de Husserl en France. Les tentatives de refondation de la phénoménologie dans la deuxième moitié du XXe siècle", w: Phénoménologie: un siècle de philosophie, ed. Pascal Dupond, Laurent Cournarie (Paris: Ellipses, 2017), 47.

18 Greisch, „Les yeux de Husserl en France”, 50.

19 Ricœur, À l'école de la phénoménologie, 9. 
w pełni wypowiedzieć dopiero w konflikcie z herezją ${ }^{20}$. „Heretyckość” fenomenologii francuskiej nie byłaby zatem dowodem na jej słabość, lecz świadczyłaby o żywotności, oryginalności, płodności, a nade wszystko dojrzałości fenomenologii w ogóle. Jak pisze Migasiński: „fenomenologowie francuscy to najbardziej radykalni «heretycy». Wychodzili oczywiście zawsze od pewnych analiz Husserla i Heideggera, ale poddawali je tak daleko idącym interpretacjom, że wprowadzały one zupełnie nowe wątki i lśniły blaskiem oryginalności"21.

Jakie są charakterystyczne cechy owej francuskiej "herezji” fenomenologicznej? Najpierw objawy odmienności zarysowały się na polu badań świadomości i intencjonalności. Pierwsze pokolenie francuskich fenomenologów cechowało badanie świata i neorealizm oraz badanie relacji z innymi i eksploracja obszaru intersubiektywności. Kładło ono nacisk na doniosłą rolę ciała ludzkiego w obu tych obszarach, na jego percepcję, ekspresję, zachowanie, relacyjność. $W$ badaniu świata przeżywanego pojawia się świadomość przedrefleksyjna i nietetyczna. Drugie pokolenie fenomenologów francuskich skupiło się nie tyle na badaniu fenomenów, co samego zjawiania się. Wydobycie samego jawienia się będzie z kolei skutkowało potrzebą kolejnych i pogłębionych redukcji. Nawiązując do Heideggera, pojawi się fenomenologia tego, co niezjawiskowe (Phänomenologie des Unscheinbaren; phénoménologie de l'inapparent), w której dominują takie kategorie, jak: życie, objawienie, samopobudzenie, immanencja. $W$ tym pokoleniu zaznaczy się silna inspiracja Heideggerowska także poprzez odejście od przedmiotowego na rzecz wydarzeniowego (Ereignis) charakteru fenomenu ${ }^{22}$. Wreszcie trzecie pokolenie fenomenologów francuskich cechuje się myślą pluralistyczną i rozproszoną. Występują w nim dalsze tendencje do przekraczania granic zjawiskowości, przy jednoczesnym otwarciu na dialog z filozofią analityczną czy kognitywistyką. Wobec tego polifonicznego i ekscesywnego krajobrazu niektórzy postulują program fenomenologii minimalistycznej ${ }^{23}$, obawiając się jej dalszych ekscesów metafizycznych, religijnych czy etycznych.

Fenomenologia francuska nie jest zatem ani obszarem jednolitym, ani monotematycznym. Cechuje ją nieustanne poszerzanie horyzontów, dążność do poszerzania pola fenomenalnego. Podejmowane zaś nowe fenomeny mają wpływ na pryncypia fenomenologiczne, które odtąd bywają redefiniowane $w$ nowych kontekstach. Nie dziwi zatem fakt, że

${ }^{20}$ Por. Leszek Kołakowski, Herezja (Kraków: Wydawnictwo ZNAK, 2010), 18.

${ }^{21}$ Migasiński, „Fenomenologia francuska jako problem”, 21.

${ }^{22}$ Hans-Dieter Gondek, László Tengelyi, Neue Phänomenologie in Frankreich (Berlin: Surhkamp, 2011), 14.

${ }^{23}$ Dominique Janicaud, La phénoménologie eclatée (Paris: Éditions de l'éclat, 1998). 
mówiąc o fenomenologii francuskiej, stwierdza się rozmaite "zwroty”. Co jednak to pojęcie oznacza?

\section{Zwrot jako paradoks}

Sam termin „zwrot” nie jest jednoznaczny. Niemieckiego die Kehre używał Heidegger na określenie zmiany swojej filozofii po Byciu $i$ czasie ${ }^{24}$. Przemiana ta polegała, ogólnie mówiąc, na przejściu od analityki egzystencjalnej jestestwa (Dasein) do bezpośredniego zapytywania o bycie jako takie ${ }^{25}$. Za hipotetyczną datę zwrotu Heideggera przyjmuje się rok 1930, choć z całą pewnością nie był to jakiś jednorazowy akt, moment zerwania, lecz proces stopniowych zmian, dających się zauważyć w tekstach powstałych między latami 1930 i 1936. Wypowiedzi samego Heideggera na temat zwrotu nie są jednoznaczne. Spośród różnych terminów niemieckich, jak die Wendung czy das Wenden, wyraźnie uprzywilejowuje on termin die Kehre. Rzeczownik ten wiąże się z czasownikiem kehren: „obracać”, "zawracać”, „wywracać”, „przenicować” i służy do wyrażania ruchu obrotowego. Kehre znaczy "skręt” (drogi lub spirali), „wygięcie”, ,zgię-

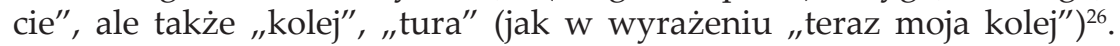
Z tego powodu komentatorzy rozumieli „,zwrot" jako przemianę w sposobie myślenia filozofa, która wyraziła się w zmianie tematyki lub zmianie akcentu podejmowanych motywów filozoficznych.

Nas w tym momencie interesuje nie tyle przedmiotowa zawartość filozofii Heideggera, ile sama problematyka Kehre i jego interpretacja. Pytamy, na czym polegał ów zwrot i jaka jest jego formalna struktura. Od razu trzeba powiedzieć, że nie ma jednej interpretacji „zwrotu” Heideggerowskiego, lecz możemy mówić o czterech jej postaciach. Pierwsza interpretacja wydaje się najbardziej oczywista - według niej zwrot to tyle, co punkt krytyczny w filozofii Heideggera, rozumiany jako przemiana i przejście od wąskiej perspektywy egzystencjalno-humanistycznej (Dasein) do szerokiej perspektywy „myślenia bycia”. W tym sensie „punkt krytyczny" rozcina niejako twórczość Heideggera na dwie zasadniczo odmienne części, przy czym pewne elementy późniejszej myśli

${ }^{24}$ Martin Heidegger, Bycie i czas, przeł. Bogdan Baran (Warszawa: Wydawnictwo Naukowe PWN, 2010).

25 Otto Pöggeler, Droga myślowa Martina Heideggera, przeł. Bogdan Baran (Warszawa: Czytelnik, 2002), 209; Bogdan Baran, Saga Heideggera (Kraków: Inter esse, 1990); Magdalena Hoły-Łuczaj, „Heideggerowski zwrot: jedność bycia i nieantropocentryczna filozofia człowieka", Acta Universitatis Lodziensis. Folia Philosophica 26 (2013): 96; Małgorzata Kwietniewska, „Zwrot w myśli Heideggera”, Analiza i egzystencja 6 (2007): 25-26; Marek Drwięga, Kim jest człowiek? Studia z filozofii człowieka (Kraków: Księgarnia Akademicka, 2013): 160-161.

${ }^{26}$ Kwietniewska, ,Zwrot w myśli Heideggera”, 30. 
filozofa znajdują swoją podstawę w myśli wcześniejszej. Sam Heidegger łagodził tak radykalne rozumienie zwrotu i dlatego należy stwierdzić, że jest to interpretacja błędna ${ }^{27}$. Tak rozumiany zwrot $\mathrm{w}$ jego filozofii nie miał miejsca.

Po drugie, określenie „zwrot” może odnosić się nie do myśli pojedynczego filozofa, lecz do przemian zachodzących w całej filozofii. W tym sensie zwrot $u$ Heideggera byłby po prostu przejawem dokonującego się w filozofii przekroczenia tradycji metafizycznej. Zwrot w tej interpretacji oznaczałby przemianę metafizycznego myślenia. Jednakże, zdaniem Heideggera, ten ostateczny zwrot $\mathrm{w}$ metafizyce, która sama przeszła kilka zwrotów, jeszcze się nie dokonał, on go dopiero anonsu$\mathrm{je}^{28}$. Co prowadzi do wniosku, że tak pojęty zwrot również $\mathrm{w}$ filozofii Heideggera nie miał miejsca.

Według trzeciej możliwej interpretacji zwrot może być rozumiany jako krok wstecz. O ile w Byciu i czasie odwołania do klasyków filozofii są nieliczne, o tyle po roku 1930 mnożą się prace, w których Heidegger drobiazgowo komentuje dzieła filozofów starożytnych, takich jak Anaksymander, Heraklit, Parmenides, Platon czy Arystoteles, a także nowożytnych, spośród których możemy wymienić: Immanuela Kanta, Friedricha Wilhelma Josepha von Schellinga i Georga Wilhelma Friedricha Hegla. Mamy do czynienia z ruchem zawracającym, z radykalną zmianą kierunku zainteresowań filozofa - następuje tu przejście od ujęć fenomenologiczno-egzystencjalnych do ujęć filologiczno-historycznych. Jak twierdzi Jean-François Mattéi, Heidegger z uporem ignoruje postępowanie naprzód filozofiii ${ }^{29}$. Taki zwrot $\mathrm{w}$ sensie odwrotu, który prowadzi w stronę niepomyślanego źródła, z całą pewnością miał miejsce w filozofii Heideggera.

Po czwarte jednak należy stwierdzić, że Heideggera lektura klasyków filozofii, co wyżej skonstatowaliśmy jako „krok wstecz”, jest jednak specyficzna. Wydobywa on momenty zapomniane w dotychczasowych badaniach metafizycznych, związane właśnie z pojęciem Kehre i ruchu: mobilność, proces, przechodzenie w siebie przeciwieństw, gra skrajności, zamienianie się przeciwieństw miejscami, cykl przemian ${ }^{30}$. Heidegger decyduje się więc odrzucić obowiązujący schemat myślenia w metafizyce Zachodu i wydobyć zapomniane oraz zamaskowane elementy. W tym sensie "krok wstecz" jest tak naprawdę „krokiem naprzód”, co

27 Przykładową wypowiedzią Heideggera może być List do Richardsona, który w przekładzie własnym podaje Małgorzata Kwietniewska, „Zwrot w myśli Heideggera", 27.

${ }^{28}$ Martin Heidegger, Identyczność i różnica, przeł. Janusz Mizera (Warszawa: Wydawnictwo Aletheia, 2010), 75.

${ }_{29}$ Dominique Janicaud, Jean-François Mattéi, La métaphysique à la limite. Cinq études sur Heidegger (Paris: PUF, 1992), 73.

30 Kwietniewska, „Zwrot w myśli Heideggera”, 33. 
odsłania jego paradoksalny charakter. Największym osiągnięciem wydobywania tego, co zapomniane, czyli wychylania się naprzód, jest dostrzeżenie zapomnienia bycia. „Krok wstecz” okazuje się wręcz skokiem (der Sprung) - to jest właściwa figura pojęciowa zwrotu, który dokonuje się w zachodniej metafizyce.

Możemy zauważyć, że cztery powyższe interpretacje zwrotu układają się W strukturę, którą można oddać terminem "chiazmu” albo krzyżowania się. Pojęcie "chiazm” pochodzi z literatury i retoryki, gdzie oznacza figurę, w której cztery terminy są pogrupowane po dwa w strukturze krzyżowej. Może być on także rozumiany jako paralelizm składniowy, polegający na powtórzeniu członu w odwróconej kolejności według schematu: podmiot-orzeczenie orzeczenie-podmiot, jak w wierszu Juliusza Słowackiego: „Grusza szeleści i szumi kłos”31. Struktury chiastycznej użył Maurice. Merleau-Ponty na opisanie relacji ciała własnego i świata ${ }^{32}$. Podobnie u nas krzyżują się cztery przywołane interpretacje zwrotu, przy czym w dwóch pierwszych zwrot nie zachodzi, w dwóch zaś kolejnych zachodzi. Możemy zatem powiedzieć, że zwrot jest i zarazem go nie ma, w czym odsłania swój paradoksalny charakter. Należy mieć to na uwadze, chcąc mówić o jakichkolwiek zwrotach $\mathrm{w}$ filozofii, w tym także $\mathrm{w}$ fenomenologii francuskiej. Na pewno zwrotu nie można rozumieć zbyt dosłownie, punktowo i technicznie. Jest to struktura złożona, dialektyczna, cykliczna i chiastyczna. Zwrot zawsze będzie paradoksem - już teraz możemy powiedzieć, że na pytanie, czy zwrot występuje, będzie musiała paść odpowiedź o formalnej strukturze: i tak, i nie.

\section{Ciało i Eros}

Tę złożoną i paradoksalną formułę „zwrotu” chcemy odnieść do fenomenologii francuskiej i zastanowić się, czy zachodzi w niej „zwrot erotyczny". W tym celu należy wpierw ukazać fenomen erotyczny jako dominantę w badaniach francuskich fenomenologów, a następnie odnieść ją do chiastycznej struktury zwrotu jako takiego. Fenomenologię erotyczności zaprezentujemy na podstawie czterech autorów: Merleau-Ponty'ego, Lévinasa, Henry'ego i Mariona.

Należy nieustannie mieć na uwadze, że badania erotyczne wpisują się w problem intersubiektywności, który przez wieki stanowił margines filozofii, a zyskał wyróżnione miejsce za sprawą fenomenologii.

${ }^{31}$ Michał Głowiński, Słownik terminów literackich (Wrocław: Ossolineum, 1989 ), 72.

32 Maurice Merleau-Ponty, Le visible et l'invisible (Paris: Gallimard, 1964), 170-201 ; Jacek Migasiński, Merleau-Ponty (Warszawa: Wiedza Powszechna, 1995), 85; Pascal Dupond, Le vocabulaire de Merleau-Ponty (Paris: Ellipses, 2001), 6-7. 
Francuskie ujęcie fenomenologii innego jest ostrym sprzeciwem wobec Husserla, którego zajmował raczej problem konstytucji drugiego, co podjął w piątej Medytacji kartezjańskiej. Twórca fenomenologii wyszedł od różnicy sposobów dania rzeczy i osób - o ile rzeczy prezentują się w obecności samodzielnej, o tyle osoby nie są samodzielne, lecz prezentują się poprzez swoje ciała ${ }^{33}$. Jakie jednak ciało ma na myśli Husserl? Rozpoznając inne osoby, rozpoznaję ich ciała nie tylko jako fizyczne bryły (Körper), ale także jako ciała przeżywane (Leib) ${ }^{34}$. Jest to możliwe dzięki tzw. przeniesieniu analogizującemu sensu żywego ciała z mojego własnego ciała na inne prezentujące się ciała. Dwa ciała - moje własne i obce - zostają połączone w parę (Paarung) w akcie ujęcia analogizującego, przy czym ujęcie to jest aktem pasywnym i prerefleksyjnym ${ }^{35}$. Takie ujęcie intersubiektywności zostało praktycznie odrzucone $\mathrm{w}$ fenomenologii francuskiej, m.in. ostro krytykował je Ricœur ${ }^{36}$. Zdaniem francuskich krytyków Husserlowi nie udało się opuścić subiektywizmu i dotrzeć do drugiego ${ }^{37}$. Drugi jest alter ego, a więc ciągle pozostajemy w przestrzeni egologicznej, a ponadto rozumowanie Husserla prowadzi do sprzeczności, gdyż ciało żywe (Leib) może być tylko moje. Inny nie może być analogonem ego, lecz stanowi odrębne i nieredukowalne doświadczenie źródłowe, które dokonuje się na poziomie pozarefleksyjnym, bez udziału percepcji zmysłowej, z silnym zaakcentowaniem pola afektywnego.

W wyniku sprzeciwu wobec Husserla w fenomenologii francuskiej ukształtowały się różne ujęcia intersubiektywności: koncepcja „spojrzenia drugiego" Sartre'a ${ }^{38}$, koncepcja inności zinterioryzowanej („Inny we

33 Edmund Husserl, Medytacje kartezjańskie, przeł. Andrzej Wajs (Warszawa: Wydawnictwo Naukowe PWN, 1982), 159-161.

34 Tamże, 141-143. To rozróżnienie będzie miało fundamentalne znaczenie dla fenomenologii francuskiej, w której Körper zostanie oddane jako le corps, a Leib jako la chair, przy wszystkich różnicach w ich ujęciu przez poszczególnych autorów.

${ }_{35}$ Tamże, 163. Por. Jarosław Jakubowski, „Paula Ricœura krytyka fenomenologii Innego", w: Wokót fenomenologii francuskiej. Możliwości, pokrewieństwa, konfrontacje, red. Iwona Lorenc, Jacek Migasiński (Warszawa: Wydawnictwo IFiS PAN, 2007), 154.

${ }^{36}$ Paul Ricœur, O sobie samym jako innym, przeł. Bogdan Chełstowski (Warszawa: Wydawnictwo Naukowe PWN, 2005), 554-555.

${ }_{37}$ Co nie oznacza, że u Husserla nie ma analiz na temat ciała i intersubiektywności cielesnej. Przykładem może być analiza pieszczoty, którą dobrze wydobywa i omawia Didier Franck. Por. Didier Franck, Dwa ciała. Wokót fenomenologii Husserla, przeł. Jacek Migasiński i Anastazja Dwulit (Warszawa: Wydawnictwo Naukowe Scholar, 2017), 187-191.

${ }^{38}$ Jean-Paul Sartre, Byt i nicość, przeł. Jan Kiełbasa i in. (Kraków; Wydawnictwo Zielona Sowa, 2007), 326 i n. 
mnie") $)^{39}$ czy koncepcja fenomenu erotycznego ${ }^{40}$. Nas interesuje trzeci typ intersubiektywności, w którym Inny daje się jako podmiot $\mathrm{w}$ formie przeżyć afektywnych, przez co egzystencja innego nie budzi wątpliwości. Intencjonalność erotyczna daje dostęp do innego jako obdarzonego własnym, podmiotowym ciałem. W relacji erotycznej dwie spotykające się cielesności wzajemnie obdarowują się swoimi doświadczeniami i przeżyciami, a w efekcie ciałami własnymi. Jednakże już w samym ujmowaniu intersubiektywności $w$ ramach fenomenologii francuskiej odnotowujemy moment polemiczny, być może nawet w pewnym sensie zwrot. Opracowanie fenomenologii Erosa jest silnym sprzeciwem wobec Sartre’a, u którego modelem uprzedmiotowienia była właśnie relacja seksualna ${ }^{41}$.

Jako pierwszy $\mathrm{w}$ fenomenologii francuskiej badania nad relacją erotyczną podjął Merleau-Ponty w Fenomenologii percepcji, umieszczając ją $\mathrm{w}$ ramach pola afektywnego ${ }^{42}$. Afektywność to szczególny sposób odnoszenia się do świata, pewien typ intencjonalności. Merleau-Ponty odrzuca dwa redukcjonistyczne rozumienia afektywności: racjonalistyczne, według którego rozum kieruje uczuciami, oraz empirystyczne, które redukuje uczucie do stanów cielesno-fizjologicznych o przebiegu mechanicznym ${ }^{43}$. Uczucia należy raczej uznać za odrębny rodzaj świadomości. Relacja erotyczna daje dostęp do ciała innego. Mogę je postrzegać jak przedmiot - będzie to wówczas percepcja obiektywna. Ale w relacji seksualnej percepcja obiektywna zostaje przeniknięta percepcją erotyczną. Ta ostatnia polega na tym, że pod ciałem, które postrzegam, rozciąga się coś, co Merleau-Ponty określa jako „indywidualny schemat seksualny" ${ }^{\prime 4}$, który uruchamia sfery erogenne i domaga się określonych gestów i przeżyć. W percepcji erotycznej odkrywamy nowy rodzaj intencjonalności. Nie jest ona jedynie świadomością czegoś, cogitatio nakierowanym na jakieś cogitatum. Percepcja erotyczna to szczególny sposób odnoszenia się mojego ciała do ciała drugiego człowieka, które ujmuje nie jako przedmiot, ale jako cel zjednoczenia ${ }^{45}$. I jako taka, percepcja seksualna

39 Emmanuel Lévinas, Inaczej niż być lub ponad istota, przeł. Piotr Mrówczyński (Warszawa: Wydawnictwo Aletheia, 2000), 114, 130; Ricœur, O sobie samym jako innym, 529-530; Michel Henry, O fenomenologii, przeł. Marek Drwięga (Warszawa: Wydawnictwo IFiS PAN, 2007), 246-260.

${ }^{40}$ Emmanuel Lévinas, Całość i nieskończoność. Esej o zewnętrzności, przeł. Małgorzata Kowalska (Warszawa: Wydawnictwo Naukowe PWN, 2012), 307-322.

41 Jean-Luc Marion, Le phénomène érotique (Paris: Grasset, 2003) ; Michel Henry, Wcielenie. Filozofia ciała, przeł. Małgorzata Frankiewicz, Dariusz Adamski (Kraków: Homini, 2012), 355-386.

${ }^{42}$ Maurice Merleau-Ponty, Fenomenologia percepcji, przeł. Małgorzata Kowalska, Jacek Migasiński (Warszawa: Wydawnictwo Aletheia, 2001), 175.

${ }^{43}$ Tamże, 175-176.

44 Tamże, 177.

45 Tamże, 178. 
dokonuje się nie w świadomości, lecz w świecie. Coś ma znaczenie seksualne tylko wtedy, gdy istnieje dla mojego ciała. W seksualności występuje dążność, by wszystkie bodźce spleść w sytuację erotyczną i odpowiedzieć na nie zachowaniem seksualnym. W percepcji erotycznej można mówić o swoistym „rozumieniu”, które nie należy do porządku intelektualnego. Rozumienie intelektu polega na tym, że intelekt wiąże doświadczenie z jakąś ideą. Tymczasem erotyczne „rozumienie” polega na tym, że wiąże ciało z innym ciałem. Seksualność to nie tylko świadomość innego ciała, ale to odniesienie się do niego dążące do zjednoczenia, zawierające wysoki stopień witalności i płodności. Słabością myśli Merleau-Ponty'ego jest wpisanie erotyzmu w schemat ciało-świat. Jak sam pisze: „Naszym stałym celem jest wydobycie na jaw pierwotnej funkcji, dzięki której przestrzeń, przedmiot lub narzędzie istnieją dla nas tak, że możemy nad nimi zapanować, oraz opisanie ciała jako miejsca takiego przywłaszczenia" ${ }^{46}$. Nie ma tu jeszcze pełnej relacji erotycznej. Mimo to dostrzeżenie ukierunkowania ciała własnego na ciało innego w celu zjednoczenia, a nie uprzedmiotowienia, jest ważnym krokiem francuskiej fenomenologii. Ponadto u Merleau-Ponty'ego funkcje świadomości intencjonalnej przejmuje ciało i jego percepcja ${ }^{47}$, a ważną funkcją ciała jest zjednoczeniowa percepcja erotyczna.

U Lévinasa fenomenologia Erosa zyskała znaczne pogłębienie ${ }^{48}$. Co prawda filozof ten najczęściej kojarzy się z etyczną relacją z Innym, jednakże w jego dziele można odnaleźć dwa typy relacji intersubiektywnej: etykę i erotykę. Nie są one poznaniem, percepcja przyswojeniem, lecz etyka oznacza wzięcie odpowiedzialności za Innego, erotyka zaś rozgrywa się „poza Twarzą” i jest ruchem miłości. Miłość u Lévinasa jest relacją dwuznaczną: z jednej strony pragnie Innego, jest ruchem transcendencji, z drugiej zaś zawiera element zmysłowy, cielesny, co Lévinas nazywa „paroksyzmem materialności" ${ }^{49}$. Inny w relacji erotycznej przybiera postać Kobiety lub Ukochanej, co ma podkreślać jego łagodność, kruchość i słabośćc0. Inny nie jawi się już jako Twarz, ale jako nagość,

${ }^{46}$ Tamże, 175.

47 Maurice Merleau-Ponty, „Prymat percepcji i jego konsekwencje filozoficzne”, przeł. Piotr Karpiński, Fenomenologia 11 (2013), 189-205; Piotr Karpiński, „Maurice Merleau-Ponty: filozofia percepcji in nucleo", Fenomenologia 11 (2013), 207-218.

${ }^{48}$ Jacek Migasiński omawia trzy różne wersje fenomenologii ciała u Husserla, Merleau-Ponty'ego i Lévinasa. Por. Jacek Migasiński, „Fenomen ciała w ujęciu Emmanuela Lévinasa”, w: Emmanuel Lévinas. Filozofia, teologia, polityka, red. Adam Lipszyc (Warszawa: Instytut Adama Mickiewicza, 2006), 14-29.

49 Lévinas, Całość i nieskończoność, 309.

${ }^{50}$ Tamże, 308. Choć Lévinas w Le temps et l'autre zastrzegał, że różnica płciowa ma charakter wyłącznie formalny, to jednak trzeźwo zauważa M. Adamiak, że kobieta, w przeciwieństwie do męskich figur, jak ojciec czy mistrz, to inność nie do końca właściwa, która nie otwiera wymiaru transcendencji. Por. Emmanuel Lévinas, Le temps et l'autre (Paris: PUF, 1983), 77-78. Marzena Adamiak, O kobiecie, która 
z czym z kolei wiąże się doświadczenie wstydu. Według Lévinasa wstyd w relacji erotycznej zostaje sprofanowany, ale nie przezwyciężony: „Profanacja polega właśnie na tym, że równocześnie odkrywa i zakrywa" ${ }^{51}$. Nie jest to jednak taki wstyd, jaki występuje u Sartre’a. Jak zauważa Józef Tischner:

Tam wstyd rodził się wzbudzony spojrzeniem drugiego, który chciał mnie zamienić w przedmiot, i był ukryciem siebie, unikiem, obroną przed urzeczowieniem. Tutaj wstyd jest znakiem właśnie obudzonej ze snu wolności, a zarazem subtelnym znakiem żyjącego we mnie Pragnienia. Nie wstydziłbym się, gdybym nie pragnął. Wstydzę się własnej swawoli. Nie chcę być swawolny wobec Drugiego, chcę być wolny. Tę wolność ofiarował mi Drugi i ja jestem mu ją winien. Drugi jest bowiem tym, kogo pragnę w moim wstydzie ${ }^{52}$.

Naturę wstydu dobrze ujawnia fenomen pieszczoty. Nie jest ona czymś czysto duchowym, empatia, współodczuwaniem ani też czymś czysto cielesnym, zmysłowym, doznaniem mechanicznym, przeżyciem fizjologicznym. Lévinas powie, że polega ona na "rozkoszowaniu się współodczuwaniem" ${ }^{25}$. W pieszczocie występuje i ciało i duch: bazą przeżycia pieszczoty są dwa nawzajem odczuwające się ciała, świadomość zaś, że drugi odczuwa, jest doświadczeniem duchowym. W pieszczotę wkrada się jednak profanacja, gdyż odkrywa ona to, co zakryte, ukazuje się w niej ciało jako nagość erotyczna. Ciało ogałaca się ze swojej formy, porzuca status bytu: nie jest ani ciałem fizjologicznym, ani narzędziem pracy, ani ekspresją Twarzy. Ten niezwykły stan znajdowania się poza bytem Lévinas nazywa dziewictwem ${ }^{54}$. Rozkosz pieszczoty ma jednak dla Lévinasa swoją logikę: w erotyzmie to, co odkryte, dalej pozostaje zakryte, nie traci swojej tajemniczości, gdyż jako korelat profanacji pojawia się wstyd $\mathrm{d}^{55}$. Na tym polega dwuznaczność Erosa - jest on odkryciem zasłaniającym.

Badania erotyczne wywołują u Lévinasa zmiany w pryncypiach fenomenologicznych. Dialektyka profanacji i wstydu w przeżyciu erotycznym sprawia, że temu ostatniemu nie można przypisać żadnej treści, jest to „intencjonalność bez widzenia”"56, czyli doświadczenie czyste. Miłość nie jest poznaniem, lecz czystym wychodzeniem poza siebie,

nawiedza myśl. Kobieta jako figura inności w koncepcji podmiotu Emmanuela Lévinasa (Warszawa: Wydawnictwo Akademickie i Profesjonalne, 2007).

${ }^{51}$ Lévinas, Całość i nieskończoność, 309.

52 Józef Tischner, Myślenie według wartości (Kraków: Wydawnictwo ZNAK, 2005), 175.

${ }^{53}$ Lévinas, Całość i nieskończoność, 310.

54 Tamże, 311.

55 Tamże, 313.

56 Tamże, 314. 
przekraczaniem siebie i własnych możliwości, jest transcendencją $q^{57}$. O ile Twarz w relacji etycznej posiada znaczenie, jakim jest apel „nie zabijesz mnie", o tyle miłość jest bez znaczenia. O ile Twarz jawi się jako wysokość, pochodzi bowiem z wymiaru boskiego, o tyle Inny w relacji erotycznej, czyli Kobieta, jawi się jako łagodność, kruchość i skłania do litości nad własną słabością. Nie znaczy to jednak, że w erotyzmie znika Twarz. Co więcej, uprzednie jej doświadczenie jest warunkiem nawiązania relacji erotycznej. Twarz Kobiety okazuje się równie dwuznaczna: przez jej znaczenie, jako Twarzy, przebija bezznaczeniowość, jako kobiecości. Na tym, zdaniem Lévinasa, zasadza się istota piękna kobiecego. Twarz Kobiety skrywa aluzje, niedopowiedzenia, dwuznaczność. To także przejaw tego, co jeszcze nieobecne. Dlatego dla Lévinasa miłość to ruch ku przyszłości. Eros wychodzi poza Twarz, nie odsłania tego, co obecne, choć zakryte, lecz to, co nieobecne. Naiwnością jest sądzić, że w miłości kochankowie oddają się sobie nawzajem. Relacja erotyczna jest przeciwieństwem relacji społecznej: „wyklucza świadków, pozostaje intymnością samotnością we dwoje, związkiem zamkniętym, niepublicznym we właściwym sensie" ${ }^{\prime 58}$. Miłość izoluje kochanków od świata i od innych ludzi, ale jednocześnie ustanawia między nimi niezwykłą więź: tworzą oni wspólnotę czującego i odczuwanego, a to jest nieprzekazywalne osobom postronnym. Dochodzimy tutaj do odkrycia prawdziwej istoty Erosa: „W rozkoszy Inny jest jednocześnie mną i kimś ode mnie oddzielonym" 59 . W miłości rozkosz jednego rozkoszuje się rozkoszą drugiego. To utożsamienie Ja i Innego w Erosie Lévinas nazywa "transsubstancjacją" i jest ona transcendencją totalną, tzn. o wiele bardziej radykalnym przekroczeniem siebie niż w relacji etycznej. Nie polega ono na tym, że obydwa podmioty zlewają się ze soba, zatracają się w sobie, lecz na tym, że płodzą dziecko. W przeżyciu erotycznym jest już zawarta relacja z kimś trzecim, z dzieckiem, które jest kimś innym i zarazem mną samym. Transcendencja radykalna spełnia się $\mathrm{w}$ byciu ojcem i synem ${ }^{60}$.

Takie ujęcie Erosa jako radykalnej transcendencji spotka się także z krytyką w ramach fenomenologii francuskiej. Twarz Innego zarówno w relacji etycznej, jak i erotycznej jest po prostu zbyt abstrakcyjna, by jakakolwiek relacja z nim była możliwa. Dlatego też Henry i Marion będą dążyć do innego ujęcia fenomenu erotycznego - pierwszy przez

57 Tamże, 316. Por. Jacek Migasiński, „Transcendentalizm Emmanuela Lévinasa", w: Wokót fenomenologii francuskiej, 121-130.

${ }^{58}$ Lévinas, Całość i nieskończoność, 320.

59 Tamże, 320.

${ }^{60}$ Piotr Karpiński, „W poszukiwaniu radykalnej transcendencji. Ojciec i syn w filozofii E. Lévinasa", Kwartalnik Naukowy Fides et Ratio 1 (2013), 139. 
osadzenie go w radykalnej immanencji, drugi zaś poszukując cech bardziej konkretnych, a nawet niezastępowalnych u kochanka.

Henry badania nad erotyzmem rozwija $w$ ramach $t z w$. fenomenologii życia ${ }^{61}$, której cechą jest traktowanie ciała jako immanencji i samo-doznaniowości (auto-affection). Dzieło Wcielenie przynosi ciekawy opis ludzkiej cielesności, doświadczanej w relacji z Innym, ale jednocześnie ujawnia się niespełniony i nieabsolutny charakter tej relacji, co Henry nazwie „porażką erotyzmu” 62 . Choć relacja erotyczna jest spotkaniem dwóch transcendentalnych cielesności, to jednak każdy z podmiotów dysponuje własnymi przeżyciami, niesprowadzalnymi do Innego. Zdaniem Henry'ego dostęp do Innego mamy poprzez ciało. Nie jest to jednak dostęp teoretyczny, jak rozumowanie czy wnioskowanie, lecz pragnienie $w$ formie spontanicznej. Doznaniowość ciała osoby A przekształca się w popędową siłę pragnienia ciała przedmiotowego osoby B. Ale ciało osoby B nie jest tylko ciałem przedmiotowym, lecz żywą cielesnością dla niej. W relacji erotycznej doznaniowość obu tych cielesności się nasila. Dopóki relację erotyczną ujmujemy jako relację ego i innego, mojej cielesności pragnącej ciała przedmiotowego innego, wówczas pozostajemy $\mathrm{w}$ dualizmie podmiot-przedmiot, co jest nie do przyjęcia, gdyż pod postacią ciała przedmiotowego Inny prezentuje się mojemu spojrzeniu jako "ego-podmiot"63.

Henry analizuje fenomen dotyku rąk mężczyzny i kobiety w tańcu. Kiedy tancerz chwyta rękę dziewczyny nie jest ona ani przez moment zredukowana do przedmiotu, gdyż „żadnemu przedmiotowi nigdy nie dane było zaznać doświadczenia bycia dotkniętym" ${ }^{\prime 64}$. Ręka dziewczyny jest dotykana, ale nie jest przedmiotem, a jej doznaniowość, czyli zdolność do bycia dotykaną, świadczy o podmiotowości i gotowości do wejścia $\mathrm{w}$ relację erotyczną. Tak więc relacja erotyczna to nie relacja podmiot-przedmiot, lecz spotkanie dwóch podmiotowości, dwóch transcendentalnych cielesności, a jedyna różnica między nimi jest taka, że jedna jest aktywna, a druga pasywna. Pasywność i aktywność to dwie modalności cielesności, które mogą zachodzić wymiennie w relacji erotycznej ${ }^{65}$. Skoro ta ostatnia to spotkanie dwóch transcendentalnych cielesności, to należy przyjąć, że relacja erotyczna „zachodzi na płaszczyźnie absolutnej immanencji, że ma swoje siedlisko w życiu"66. Wyłania się

${ }_{61}$ Michel Henry, Phénoménologie matérielle (Paris: PUF, 1990).

${ }^{62}$ Henry, Wcielenie, 363; Piotr Karpiński, „Porażka erosa w fenomenologii Michela Henry'ego", w: Motyw miłości w wybranych tekstach literackich i innych dziedzinach kultury, red. Paulina Szymczyk, Ewelina Chodźko (Lublin: Wydawnictwo Naukowe Tygiel, 2018), 48.

${ }^{63}$ Henry, Wcielenie, 358.

${ }^{64}$ Tamże, 359.

65 Tamże, 360.

66 Tamże, 361. 
zatem pytanie, czy w relacji erotycznej życie poznaje życie. Terminem „życie” Henry określa doznaniowość cielesności, doznawanie samego siebie $^{67}$. W relacji erotycznej występuje komunikacja jednej doznaniowości z druga, ale czy jedna sobośćc ${ }^{68}$ dosięga drugiej w jej własnym życiu? Czy erotyzm jest tym, co daje dostęp do życia innego? Niestety, odpowiedź Henry'ego jest negatywna: „W seksualności erotyczne pragnienie dosięgnięcia innego w jego życiu samym zderza się z porażką której nie sposób przezwyciężyć" 69 .

Porażka erotyzmu jest podwójna: to porażka pragnienia oraz porażka jawienia się świata. Erotyzm jest pragnieniem, by drugiego dosięgnąc $\mathrm{w}$ jego życiu, tam, gdzie ono samo siebie dosięga w swej własnej źródłowej cielesności, a tego nigdy nie osiągnie. Akt seksualny zespala dwa ruchy popędowe, które są na przemian aktywne i pasywne, rozpościerają się i ustępuja jednakże każdy popęd poznaje tylko samego siebie, zna swój własny ruch. Podobnie porażka erotyzmu powtarza się $\mathrm{w}$ jawieniu się świata. Ciało nagie, dotykane i pieszczone staje się ciałem przedmiotowym, a jego jawienie się możliwe jest tylko w zewnętrzności, $\mathrm{w}$ horyzoncie świata, a nie $\mathrm{w}$ doznaniowej immanencji. Erotyzm nie daje więc dostępu do transcendentalnej cielesności innego. Henry, podkreślając porażkę relacji erotycznej, dojdzie do wniosku, że nie pozwala ona na poznanie życia, gdyż to jest czystym doznawaniem samego siebie i może się jawić tylko w immanencji. Dlatego też zwróci się do rozwijania innej koncepcji intersubiektywności - „innego we mnie”. Niemniej badania erotyczne pozwoliły mu zgłębić istotę życia i utwierdzić jego fenomenologię radykalna, która zrywa z fundamentalnymi zasadami fenomenologii Husserla, jak powrót do rzeczy samych czy źródłowość samej naoczności ${ }^{70}$.

Fenomen erotyczny zostaje podjęty z całą mocą przez Mariona, który wpisuje go w niezwykle szeroką perspektywę, jaką jest program przekroczenia metafizyki ${ }^{71}$. Filozofia zapomniała bowiem o miłości, a oparła się na nowożytnym rozumie naukowym. Filozofia miłości u Mariona to

${ }^{67}$ Tamże, 31 i 116. Por. Piotr Karpiński, Odstanianie cielesności. Wieloaspektowa problematyka ciała w fenomenologii francuskiej (Kraków: Wydawnictwo WAM, 2020), 225-234.

${ }^{68}$ Pojęcie "sobości” jest charakterystyczne dla fenomenologii francuskiej i wiąże się z tzw. słabą podmiotowością. Już Ricœur zauważył, że po Nietzschem, Freudzie, Heideggerze nie da się mówić o silnym podmiocie, jak u Kartezjusza, lecz o podmiocie osłabionym. Odtąd zamiast Ja (fr. Je) używa się określenia sobość (fr. soi), by podkreślić, że uchwycenie Ja jest możliwe tylko w trzeciej osobie, a więc niejako z zewnątrz, przez wytwory i jej hermeneutykę. Por. Ricœur, O sobie samym jako innym, $5-7$.

69 Henry, Wcielenie, 363.

70 Henry, O fenomenologii, 112-144.

${ }^{71}$ Marion, Le phénomène érotique, 20. Por. tenże, „La fin de la «fin de la métaphysique»", Laval théologique et philosophique 1 (1986), 23-33 ; tenże, „La «fin de la 
sprzeciw wobec Kartezjusza, którego medytacje metafizyczne powinny uzupełnić medytacje erotyczne, i oparcie się na idei „trzeciego porząd$\mathrm{ku}^{\prime \prime}$ Blaise'a Pascala ${ }^{72}$. U Mariona zatem pojawia się nie tylko badanie fenomenu erotycznego, lecz budowany jest program przekroczenia metafizyki, polegający na "kroku wstecz”, by odnaleźć zagubioną ideę miłości i na jej bazie zrobić „,krok naprzód”, czyli ustanowić nowy paradygmat, nie metafizyczny, lecz erotyczny właśnie.

Pierwszym krokiem takiego przedsięwzięcia jest krytyka paradygmatu przedmiotowego, którego twórca jest Kartezjusz, a który dominuje także u Husserla ${ }^{73}$. Pewność naukowa, która waloryzuje jedynie ilościowe aspekty rzeczywistości, zostaje zastąpiona przez fenomenologię donacji. Dzięki tej ostatniej możemy badać wszystko, co w jakikolwiek sposób się daje, nawet nie naocznie. W efekcie zmienia się koncepcja podmiotu - ego cogito zostaje zastąpione przez ego amans, do którego prowadzi nowy typ redukcji - redukcja erotyczna, a jej narzędziem jest pytanie: „czy ktoś mnie kocha?” (m'aime-t-on?) ${ }^{74}$. Tym samym odwrócony zostaje porządek kartezjański - należy wyjść nie od faktu myślenia i pewności istnienia, lecz od faktu, że zanim istnieję, już kocham. W redukcji erotycznej podmiot nie ma w sobie nic z bytu, żadnej przedmiotowości, jest zredukowany do odpowiedzi na pytanie, czy jest kochany. Redukcja erotyczna pozwala zatem zobaczyć kochanka (amant) jako obdarowanego (l'adonné $)^{75}$, ciało (la chair) jako otrzymane od innego ${ }^{76} \mathrm{i}$ miłość jako zawsze otrzymaną skądinąd (d'ailleurs) ${ }^{77}$. Redukcja erotyczna zamyka nastawienie naturalne i metafizykę. Ego amans nie odróżnia się swoim cogitatio, dla niego także bycie nie jest już problemem, istnieje on tylko, w miarę jak kocha i jest kochany. Jest to koncepcja „miłości bez by$\mathrm{cia}^{\prime 78}$, a także nowy rodzaj pewności: już nie ugruntowana w ego cogito pewność (certitude), lecz płynące od innego zapewnienie (assurance $)^{79}$. Miłość jest fenomenem, który nie jest ugruntowany w żadnym Ja - ukazuje się on, w miarę jak Inny przychodzi do mnie i pobudza mnie, wychodząc od samego siebie. Co ważne, ja go nie konstytuuję, nie kieruję

métaphysique» comme possibilité", w: Heidegger, ed. Maxcence Caron (Paris: Cerf, 2006), 11-38.

72 Blaise Pascal, Myśli, przeł. Tadeusz Żeleński (Boy) (Warszawa: Instytut Wydawniczy PAX, 1997), 318.

73 Wojciech Starzyński, Neokartezjanizm fenomenologii francuskiej (Warszawa: Wydawnictwo IFiS PAN, 2014), 257; Marion, Le phénomène érotique, 25-33; tenże, Certitudes négatives (Paris: Grasset, 2010), 16-17.

74 Tenże, Le phénomène érotique, 39.

75 Tamże, 42.

76 Tamże, 191.

77 Tamże, 45.

78 Tamże, 17.

79 Tamże, 38. 
ku niemu intencjonalnego spojrzenia, to raczej on nadaje znaczenie mnie i przywraca mnie samemu sobie, wyrywając z próżności bytu.

Relacja erotyczna według Mariona możliwa jest tylko w ciele ${ }^{80}$, przy czym pojawia się trzeci, obok corps i chair, wymiar cielesności, ciało zerotyzowane (la chair érotisée), które może lepiej nazywać ciałem kochanym $^{81}$. Ciało nie jest już cechą sobości, ale staje się miejscem, w którym fenomenalizuje się miłość. Kochankowie w relacji erotycznej indywidualizują się nawzajem, ale czynią to poprzez pragnienie, które odsłania ich braki. Tylko Inny może odpowiedzieć na braki kochanka. W miłosnym skrzyżowaniu ciał (la croisée des chairs) każdy z kochanków otrzymuje od innego swoje ciało ${ }^{82}$. Czym się różni ciało zerotyzowane (la chair érotisée) od innych ciał świata (le corps)? Te ostatnie można poznać po tym, że są przestrzenne, to znaczy stawiają opór, natomiast w miłosnym spotkaniu ciało żywe nie stawia oporu, ale otwiera się przed Innym, zaprasza go, jest pasywne i uległe. Spotkanie z ciałem fizycznym jest cierpieniem, natomiast ciało innego w miłości nie zadaje bólu. Ciało kochanka odczuwa, że pod jego wpływem ciało innego nie stawia oporu, czyli erotyzuje się wówczas zaczyna odczuwać samo siebie. W tym sensie Marion twierdzi, że drugi daje nam nasze ciało i w efekcie przywraca nas samym sobie. Moja fenomenalność zależy więc od drugiego, jest od niego otrzymana, nie istnieję przez siebie, lecz przez innego.

W redukcji erotycznej zmienia się koncepcja czasu i przestrzeni. Przyszłość to oczekiwanie na ciało innego, teraźniejszość to moment, w którym inność się wydarza, a przeszłość jest wtedy, gdy inność przekroczyła moment swojej teraźniejszości ${ }^{83}$. Przyszłość polega na oczekiwaniu, że drugi da mi ciało. Trwa ono tak długo, aż ciało drugiego przestanie się opierać i pozwoli innemu ciału się przybliżyć. Z kolei Inny oczekuje, bym przyjął ciało, a tym samym własną sobość, indywidualność. W teraźniejszości erotycznej dokonuje się skrzyżowanie ciał, którego główną osią jest opóźnienie swojego nadejścia, nie-kończenie. Kiedyś jednak musi się ono zakończyć - wówczas przestaję na innego oczekiwać, przestaję odczuwać jego ciało i w efekcie przestaję otrzymywać swoje ciało. Przeszłość ma także cielesny charakter. W zawieszeniu erotyzacji zawiesza się ciało zerotyzowane i staje się na powrót zwykłym ciałem (le corps) dla innego. Wraz ze zniknięciem ciał jako la chair podmioty nie są już kochankami, lecz bytami światowymi i wówczas odkrywają swoją nagość. Wstyd nagości nie pojawia się w wyniku redukcji erotycznej, ale w wyniku jej zawieszenia. Marion w tym miejscu

80 Marion, La rigueur des choses. Entretiens avec Dan Arbib (Paris: Flammarion, 2012), 197.

81 Tenże, Le phénomène érotique, 196.

82 Tamże, 215.

83 Tamże, 59-67. 
przedstawia nową interpretację grzechu pierworodnego. Nie polega on na nieposłuszeństwie Bogu, lecz na wyjściu z ciał jako la chair i powrocie do świata naturalnego ${ }^{84}$. Tylko miłość chroni przed grzechem pierworodnym, bo tylko ona utrzymuje nasze ciała jako la chair w ciągłym procesie donacji i recepcji. W tej logice Bóg jako l'Amant stał się ciałem (la chair), by dać nam nasze ciała, śmierć zaś jest spotkaniem erotycznym, nieskończonym złączeniem ciał, które nie zna końca ani zawieszenia. Wieczność staje się substancją miłości i czasu fenomenu erotycznego.

$\mathrm{W}$ ten sposób fenomenologia Erosa przechodzi u Mariona w teologię, dyskurs erotyczny staje się sposobem mówienia o Bogu. Teologia nie może być onto-teologia, tzn. nie można ujmować Boga w kategoriach metafizycznych ${ }^{85}$. Możliwa jest za to teologia fenomenologiczna, która podejmuje Boga takiego, jakim On sam się daje, wychodząc od samego siebie ${ }^{86}$. Fenomen erotyczny staje się miejscem własnym teologii, gdyż zawiesza metafizyczne pytanie o bycie. Mamy tu wyraźną próbę przekroczenia metafizyki. Marion opisuje miłość jako fenomen wolny od wszelkich określeń ontologicznych i w tym sensie jako fenomen teologiczny. Le Phénomène érotique stanowi spełnienie myśli Mariona, gdyż linia fenomenologiczna zbiega się w nim z linią teologiczną. Musi tu być jednak spełniony podstawowy warunek, jakim jest jedność logiki miłości, tzn. opis fenomenu erotycznego w doświadczeniu ludzkim zachowuje swoją ważność dla miłości, jaką kocha Bóg. Książka kończy się słynnym zdaniem: „Bóg jest najlepszym kochankiem” (Dieu est le meilleur amant $)^{87}$. Tutaj widzimy, jak o wiele bardziej fenomenologia potrzebuje teologii niż teologia fenomenologii. Wiara staje się warunkiem fenomenalizacji fenomenów niewidzialnych z porządku "serca”, a dostępu do nich nie daje nam już rozum dyskursywny, naukowy, lecz „wielki rozum" - ciało człowieka. Marion określił ludzką cielesność mianem „wielkiego rozumu", który pozwala nam poznać to, co w życiu najistotniejsze - miłość właśnie ${ }^{88}$.

\section{Zwrot erotyczny? - konkluzje}

Powyżej nakreślony obraz pokazuje, że badania erotyczne w fenomenologii francuskiej są nie tylko wszechstronne i ciekawe, ale co więcej-

84 Pascale Tabet, Amour et donation chez Jean-Luc Marion (Paris: L'Harmattan, 2017), 175.

${ }^{85}$ Jean-Luc Marion, Idol $i$ dystans, przeł. Wojciech Starzyński, Urszula Idziak-Smoczyńska (Kraków: Wydawnictwo WAM, 2016), 22-30.

86 Tenże, Bóg bez bycia, przeł. Małgorzata Frankiewicz (Kraków: Wydawnictwo ZNAK, 1996), 78.

87 Marion, Le phénomène érotique, 369.

${ }^{88}$ Tenże, „Wiara i rozum”, przeł. Piotr Karpiński, Fenomenologia 16 (2018), 15-23. 
mają na tyle poważne skutki dla samej fenomenologii, że upoważniają do pytania, czy mamy do czynienia ze zwrotem erotycznym $w$ fenomenologii francuskiej. By na to pytanie odpowiedzieć, należy mieć na uwadze paradoksalny charakter samego „zwrotu”, co pokazaliśmy na przykładzie myśli Heideggera. Ujawniła się jego struktura chiazmu i paradoksalny charakter - zwrot występuje i nie występuje zarazem.

Jeśli potraktujemy zwrot jako „punkt krytyczny”, rozcinający dzieje fenomenologii na dwie części, to $w$ tym sensie zwrot erotyczny $w$ fenomenologii francuskiej nie występuje. Wprawdzie Husserl i Heidegger nie zajmowali się erotyzmem jako zagadnieniem zbyt regionalnym i szczegółowym, ale też pojawienie się erotyzmu nad Sekwaną nie wzięło się znikąd. Należy przyjąć następującą tezę: wiele nierozwiniętych, niewystarczająco opracowanych, a niekiedy ledwo zasygnalizowanych kwestii u Husserla i Heideggera podziałało jak milcząca wskazówka dla fenomenologów francuskich. Jedną z nich jest problematyka ciała ludzkiego. Przy czym, by taka wskazówka mogła mieć znaczenie, nie może być mowy o całkowitym „milczeniu” o ciele w klasycznej fenomenologii niemieckiej. Uwzględnienie i dalsze eksplorowanie ludzkiej cielesności przez fenomenologów francuskich doprowadziło do badań nad relacją erotyczna, a w efekcie do przemian samych pryncypiów fenomenologicznych. Tytułem przykładu można tu wymienić przejęcie przez percepcyjne ciało funkcji świadomości intencjonalnej, źródłowy charakter nie naoczności, lecz doznaniowości, intencjonalność odwróconą czy odejście od konstytuowania sensów przedmiotowych na rzecz wydarzania się fenomenu. Ponadto fenomenologowie francuscy często stosowali metodę tzw. repryzy, czyli kolejnego, pogłębiającego podejmowania tych samych zagadnień. W tym sensie żadną miarą nie można mówić o zwrocie erotycznym $\mathrm{w}$ fenomenologii francuskiej.

Jeśli z kolei zwrot erotyczny umieścimy w szerszej perspektywie filozoficznej, jako przejaw obecnego w filozofii XX wieku przezwyciężania metafizyki, to taki zwrot $w$ całej fenomenologii francuskiej również nie zachodzi. Dużo się mówi w fenomenologii francuskiej o konieczności przezwyciężenia metafizyki, ale jest to bardziej postulat niż krok dokonany. Możemy odnotować pewne symptomy przezwyciężania metafizyki, jak odchodzenie od perspektywy przedmiotowej w badaniu fenomenów na rzecz ich wydarzeniowości. Ale można też skwitować to stwierdzeniem, że w fenomenologii francuskiej silnie zaznaczyła się recepcja Heideggera i jego koncepcji Ereignis. A poza tym silnie obecna jest $\mathrm{w}$ niej tendencja metafizyczna, co pokazał w swoich badaniach Jacek Migasiński.

Zwrot może być jednak rozumiany jako „krok wstecz” i powrót do zapomnianych fenomenów. $W$ tym sensie $w$ fenomenologii francuskiej zwrot erotyczny występuje. Należy go rozumieć w pierwszej kolejności jako powrót do zagadnienia ciała. Dla wszystkich przywołanych przez 
nas francuskich autorów fenomenologia bez ciała nie istnieje. Ale „krok wstecz" w fenomenologii francuskiej to także powrót do takich fenomenów, jak Inny, miłość czy fenomen religijny.

Wreszcie, po czwarte, zwrot może być „krokiem naprzód”. Podejmowanie zapomnianych fenomenów jest tak specyficzne i w tak nowy sposób, że skutkuje zbudowaniem nowego paradygmatu myślowego. W tym najpełniejszym sensie zwrot erotyczny występuje u Mariona, dla którego miłość jest nowym paradygmatem filozofii. W paradygmacie erotycznym sama fenomenologia doznała znaczących przekształceń względem klasycznych założeń. Ma ona swoje narzędzie, jakim jest redukcja erotyczna. Zmienia ona podmiot ego cogito w ego amans. Zmienia się pewność naukowa i przedmiotowa (certitude) w zapewnienie (assurance) o bardziej etycznym charakterze. $\mathrm{W}$ paradygmacie erotycznym zmienia się czas i przestrzeń. Wreszcie miłość staje się w opozycji do onto-teologii możliwym sposobem myślenia Boga - umożliwia realizację idei „Boga bez bycia”.

Reasumując, należy potwierdzić to, co odsłaniało się już wcześniej $\mathrm{w}$ naszych refleksjach - zwrot erotyczny $\mathrm{w}$ fenomenologii francuskiej występuje i zarazem nie występuje. Nie jest on punktem krytycznym, po którym coś nowego w fenomenologii się zaczęło, ani też nie oznacza przezwyciężenia metafizyki, która w zmienionych kształtach trzyma się całkiem nieźle. Zwrot erotyczny należy rozumieć jako powrót do zapomnianego fenomenu miłości i takie przemyślenie go, które skutkować będzie rozwojem fenomenologii. Czy jednak ów zwrot oznacza przeciwieństwo wobec myślicieli sprzed niego? Okazuje się, że bez nich nie byłby w ogóle możliwy. Można sparafrazować Heideggera i powiedzieć, że klasycy fenomenologii i reformatorzy razem tworzą „ontologiczną całość'"89, a zwrot jest wewnętrznym i dialektycznym ruchem fenomenologii.

\section{Bibliografia}

Adamiak Marzena. 2007. O kobiecie, która nawiedza myśl. Kobieta jako figura inności w koncepcji podmiotu Emmanuela Lévinasa. Warszawa: Wydawnictwo Akademickie i Profesjonalne.

Baran Bogdan. 1990. Saga Heideggera. Kraków: Inter esse.

Clavier Paul. 2005. „Un tournant gnostique de la phénoménologie française?: À propos des Paroles du Christ de Michel Henry". Revue Thomiste 2: 307-315.

Depraz Natalie. 2004. „Le tournant pratique de la phénoménologie française". Revue philosopique de la France et de l'Étranger 2: 149-165.

${ }^{89}$ Heidegger, Bycie i czas, 308. 
Depraz Natalie. 2010. Zrozumieć fenomenologię. Konkretna praktyka, przeł. Agata Czarnacka. Warszawa: Oficyna Naukowa.

Drwięga Marek. 2013. Kim jest człowiek? Studia z filozofii człowieka. Kraków: Księgarnia Akademicka.

Dupond Pascal. 2001. Le vocabulaire de Merleau-Ponty. Paris: Ellipses.

Franck Didier. 2017. Dwa ciała. Wokót fenomenologii Husserla. Warszawa: Wydawnictwo Naukowe Scholar.

Gilbert Paul. 2002. „Le tournant ontologique de la phénoménologie française?", Nouvelle Revue Théologique 124-4: 597-617.

Głowiński Michał. 1989. Słownik terminów literackich. Wrocław: Ossolineum.

Gondek Hans-Dieter, Tengelyi László. 2011. Neue Phänomenologie in Frankreich. Berlin: Surhkamp.

Greisch Jean. 2017. „Les yeux de Husserl en France. Les tentatives de refondation de la phénoménologie dans la deuxième moitié du $\mathrm{XX}^{\mathrm{e}}$ siècle". W: Phénoménologie: un siècle de philosophie, ed. Pascal Dupond, Laurent Cournarie, 45-74. Paris: Ellipses.

Grondin Jean. 2003. Le tournant hermenutique de la phénoménologie française. Paris: PUF.

Heidegger Martin. 2010. Bycie i czas, przeł. Bogdan Baran. Warszawa: Wydawnictwo Naukowe PWN.

Heidegger Martin. 2010. Identyczność i różnica, przeł. Janusz Mizera. Warszawa: Wydawnictwo Aletheia.

Henry Michel. 2007. O fenomenologii, przeł. Marek Drwięga. Warszawa: Wydawnictwo IFiS PAN.

Henry Michel. 1990. Phénoménologie matérielle. Paris: PUF.

Henry Michel. 2012. Wcielenie. Filozofia ciała, przeł. Małgorzata Frankiewicz, Dariusz Adamski. Kraków: Homini.

Hoły-Łuczaj Magdalena. 2013. „Heideggerowski zwrot: jedność bycia i nieantropocentryczna filozofia człowieka". Acta Universitatis Lodziensis. Folia Philosophica 26: 95-112.

Husserl Edmund. 1982. Medytacje kartezjańskie, przeł. Andrzej Wajs. Warszawa: Wydawnictwo Naukowe PWN.

Jakubowski Jarosław. 2007. „Paula Ricœura krytyka fenomenologii Innego”. W: Wokół fenomenologii francuskiej. Możliwości/pokrewieństwa/konfrontacje, red. Iwona Lorenc, Jacek Migasiński, 150-166. Warszawa: Wydawnictwo IFiS PAN.

Janicaud Dominique. 1998. La phénoménologie eclatée. Paris: Éditions de l'éclat. Janicaud Dominique. 1991. Le tournant théologique de la phénoménologie française. Combas: Éditions de l'éclat.

Janicaud Dominique, Mattéi Jean-François. 1992. La métaphysique à la limite. Cinq études sur Heidegger. Paris: PUF.

Karpiński Piotr. 2013. „Maurice Merleau-Ponty: filozofia percepcji in nucleo”. Fenomenologia 11: 207-218.

Karpiński Piotr. 2020. Odsłanianie cielesności. Wieloaspektowa problematyka ciała w fenomenologii francuskiej. Kraków: Wydawnictwo WAM. 
Karpiński Piotr. 2018. „Porażka erosa w fenomenologii Michela Henry'ego”. W: Motyw miłości w wybranych tekstach literackich i innych dziedzinach kultury, red. Paulina Szymczyk, Ewelina Chodźko, 43-52. Lublin: Wydawnictwo Naukowe Tygiel.

Karpiński Piotr. 2013. „W poszukiwaniu radykalnej transcendencji. Ojciec i syn w filozofii E. Lévinasa". Kwartalnik Naukowy Fides et Ratio 1: $128-142$.

Kołakowski Leszek. 2010. Herezja. Kraków: Wydawnictwo Znak.

Kwietniewska Małgorzata. 2007. „Zwrot w myśli Heideggera”. Analiza i egzystencja 6: 25-48.

Leclercq Bruno. 2003. „Compte-rendu de Tom Dedeurwaerdere, Action et contexte: Du tournant cognitiviste à la phénoménologie transcendantale". Recherches Husserliennes 20: 115-118.

Lévinas Emmanuel. 2012. Całość i nieskończoność. Esej o zewnętrzności, przeł. Małgorzata Kowalska. Warszawa: Wydawnictwo Naukowe PWN.

Lévinas Emmanuel. 2000. Inaczej niż być lub ponad istota, przeł. Piotr Mrówczyński. Warszawa: Wydawnictwo Aletheia.

Lévinas Emmanuel. 1983. Le temps et l'autre. Paris: PUF.

Lorenc Iwona. 2006. „Ścieżki ku rzeczom samym współczesnej fenomenologii francuskiej". W: Fenomenologia francuska. Rozpoznania/interpretacjel rozwinięcia, red. Jacek Migasiński, Iwona Lorenc, 30-66. Warszawa: Wydawnictwo IFiS PAN.

Marion Jean-Luc. 1996. Bóg bez bycia, przeł. Małgorzata Frankiewicz. Kraków: Wydawnictwo Znak.

Marion Jean-Luc. 2010. Certitudes négatives. Paris: Grasset.

Marion Jean-Luc. 2016. Idol $i$ dystans, przeł. Wojciech Starzyński, Urszula Idziak-Smoczyńska. Kraków: Wydawnictwo WAM.

Marion Jean-Luc. 1986. „La fin de la «fin de la métaphysique»”. Laval théologique et philosophique 1: 23-33.

Marion Jean-Luc. 2006. „La «fin de la métaphysique» comme possibilité”. W: Heidegger, ed. Maxcence Caron, 11-38. Paris: Cerf.

Marion Jean-Luc. 2012. La rigueur des choses. Entretiens avec Dan Arbib. Paris: Flammarion.

Marion Jean-Luc. 2003. Le phénomène érotique. Paris: Grasset.

Marion Jean-Luc. 2002. „Un moment français de la phénoménologie”. Rue Descartes. Collège international de philosophie. Mars: 9-13.

Marion Jean-Luc. 2018. „Wiara i rozum”, przeł. Piotr Karpiński. Fenomenologia 16: 11-23.

Merleau-Ponty Maurice. 2001. Fenomenologia percepcji, przeł. Małgorzata Kowalska, Jacek Migasiński. Warszawa: Wydawnictwo Aletheia.

Merleau-Ponty Maurice. 1964. Le visible et l'invisible. Paris: Gallimard.

Merleau-Ponty Maurice. 2013. „Prymat percepcji i jego konsekwencje filozoficzne", przeł. Piotr Karpiński. Fenomenologia 11: 189-205.

Migasiński Jacek. 2006. „Fenomen ciała w ujęciu Emmanuela Lévinasa”. W: Emmanuel Lévinas. Filozofia, teologia, polityka, red. Adam Lipszyc, 14-29. Warszawa: Instytut Adama Mickiewicza. 
Migasiński Jacek. 2006. „Fenomenologia francuska jako problem. Topografia «herezji»". W: Fenomenologia francuska. Rozpoznania/interpretacje/rozwinięcia, red. Jacek Migasiński, Iwona Lorenc, 7-29. Warszawa: Wydawnictwo IFiS PAN.

Migasiński Jacek. 1995. Merleau-Ponty. Warszawa: Wiedza Powszechna.

Migasiński Jacek. 2007. „Transcendentalizm Emmanuela Lévinasa”. W: Wokót fenomenologii francuskiej. Możliwości/pokrewieństwa/konfrontacje, red. Iwona Lorenc, Jacek Migasiński, 105-134. Warszawa: Wydawnictwo IFiS PAN.

Migasiński Jacek. 1997. W strone metafizyki. Nowe tendencje metafizyczne w filozofii francuskiej XX wieku. Wrocław: Fundacja na Rzecz Nauki Polskiej.

Pascal Blaise. 1997. Myśli, przeł. Tadeusz Żeleński (Boy). Warszawa: Instytut Wydawniczy PAX.

Płotka Witold. 2014. „Słowo wstępne”. W: Wprowadzenie do fenomenologii. Interpretacje, zastosowania, problemy, red. Witold Płotka, 7-27. Warszawa: Wydawnictwo IFiS PAN.

Pöggeler Otto. 1990. Droga myślowa Martina Heideggera, przeł. Bogdan Baran. Warszawa: Czytelnik.

Ricœur Paul. 2004. A l'école de la phénoménologie. Paris: Vrin.

Ricœur Paul. 2005. O sobie samym jako innym, przeł. Bogdan Chełstowski. Warszawa: Wydawnictwo Naukowe PWN.

Saison Maryvonne. 1999. „Le tournant esthétique de la phénoménologie”. Revue d'esthétique 36 (1999): 125-140.

Sartre Jean-Paul. 2007. Byt i nicość, przeł. Jan Kiełbasa i in. Kraków: Wydawnictwo Zielona Sowa.

Starzyński Wojciech. 2014. Neokartezjanizm fenomenologii francuskiej. Warszawa: Wydawnictwo IFiS PAN.

Tabet Pascale. 2017. Amour et donation chez Jean-Luc Marion. Paris: L'Harmattan.

Tischner Józef. 2005. Myślenie według wartości. Kraków: Wydawnictwo Znak. Waldenfels Bernhard. 1983. Phänomenologie in Frankreich. Frankfurt am Main: Suhrkamp.

\section{Streszczenie}

Jednym ze sposobów na opisanie przemian $\mathrm{w}$ ramach ruchu fenomenologicznego jest anonsowanie kolejnych „zwrotów”. Najbardziej znany to ogłoszony w 1991 roku przez Dominiquéa Janicauda „zwrot teologiczny w fenomenologii francuskiej", ale mówi się także o zwrocie estetycznym, kognitywistycznym $\mathrm{i}$ innych. W artykule chcemy zbadać, czy w fenomenologii francuskiej wystąpił zwrot erotyczny, a to za sprawą ważnego miejsca, jakie zajmują u poszczególnych autorów badania cielesności, miłości, erotyki i seksualności. Najpierw ukazujemy fenomenologię francuską jako miejsce żywiołowych przemian, ekscesów i zwrotów. Następnie przyglądamy się samej strukturze zwrotu, odnosząc 
się do Heideggerowskiego die Kehre jako paradygmatu zwrotu. Jest to zasadne, gdyż fenomenologia francuska o wiele bardziej wyrasta z myśli Heideggera niż Husserla. Interpretacja terminu „zwrot” nie jest jednoznaczna i można mówić o jej czterech wersjach, które razem wzięte układają się w strukturę chiazmu. Po odniesieniu jej do badań erotycznych u fenomenologów francuskich należy stwierdzić, że „zwrot erotyczny” w fenomenologii francuskiej jednocześnie jest i go nie ma, czyli ma charakter paradoksu. Nie występuje on, jeśli rozumieć go jako punkt krytyczny i nowy początek, względnie jako definitywne przekroczenie metafizyki. Natomiast możemy go odnotować jako powrót do zapomnianych fenomenów, jak cielesność, intersubiektywność, relacja erotyczna. Dodatkowo u Jeana-Luca Mariona mamy do czynienia z próbą sformułowania nowej filozofii i teologii, opartych na fenomenie erotycznym, co pokazuje zwrot jako krok naprzód.

Słowa kluczowe: ciało, Eros, fenomenologia, Henry, Lévinas, Marion, miłość, Merleau-Ponty.

\section{Erotic Turn in French Phenomenology?}

\section{Summary}

One way to describe changes in the phenomenological movement is to announce the next "turns". The best known is the "theological turn in French phenomenology" announced in 1991 by Dominique Janicaud, but there is also talk of an aesthetic, cognitive and other turn. In this paper, we want to investigate whether we can tell about an erotic turn in French phenomenology, and this is because of the important place in the study of corporeality, love, eroticism and sexuality in French authors. First, we show the French phenomenology as a place of spontaneous changes, excesses and turns. Then we look at the structure of turn, referring to Heidegger's die Kehre as the paradigm. This is justified, since French phenomenology is much more rooted in Heidegger's thought than in Husserl's. Interpretation of the term "turn" is ambiguous and we may speak of its four versions, which, taken together, form a chiasmic structure. After referring to it erotic studies in French phenomenologists, it should be stated that the "erotic turn" in French phenomenology exists and in the same time does not exist, that is, it has the character of a paradox. The erotic turn does not occur if understood as a critical point and a new beginning, or as a definitive transgression of metaphysics. However, we can note it as a return to forgotten phenomena, such as corporeality, intersubjectivity, and erotic relationship. Jean-Luc Marion attempts to formulate a new philosophy and theology based on the erotic phenomenon, which shows the turn as a step forward.

Keywords: body, Eros, Henry, Lévinas, love, Marion, Merleau-Ponty, phenomenology 